\title{
Doctor, soldier, scientist, and shikari
}

\author{
TESSA RICHARDS
}

Christmas Eve, Gauhati, Assam, 1930, and Colonel and Mrs Shortt were contemplating a quiet evening wrapping Christmas presents when the request came. "Would the sahib come and shoot the tiger?" The tiger in question had slaughtered cattle very close to a neighbouring village and the villagers were understandably concerned.

This was not the sort of challenge that the colonel refused. A man was sent to build a machan (tree platform about 10 feet high) overlooking the kill; Hobby, the colonel's wife, packed warm clothes and sandwiches; and the colonel prepared his rifle. The vigil began and some six hours later, after night had fallen, the chatter of the birds and monkeys changed. The tiger was approaching. Waiting until he judged the tiger had seized its kill the colonel pointed his rifle towards the noise and switched on the torch attached to its barrel. The tiger, surprised, was lit up a mere eight yards away. Seconds later it was dead.

I saw the skin of this magnificent beast when I visited the colonel at his home in Alton recently to hear something of his life, work, and memories of India working in the Indian Medical Service. At 100 years old Colonel Shortt can not only remember every detail of this tiger shoot and many other of his adventures as a shikari (hunter) of big game but also all the important details of some 60 years' work as a protozoologist-work which led, apart from some 170 publications, to three major discoveries: an effective treatment for kala azar, proof that the disease was transmitted by sandflies, and the discovery in the late 1940s of the missing link in the life cycle of the malaria parasite.

Born in the Punjab in 1887, Henry Edward Shortt was an early captive to India's peculiar magic. By the age of 7 , when he was sent to school in Inverness, his thoughts always centred on India and his father, who inspired him both with a love of natural history and a passion for sport. When he later went up to Aberdeen University to read medicine, shooting and fishing remained essential occupations and his prowess on the hockey field (he was selected to play for Scotland) clearly meant more to him than the 12 medals he received during his undergraduate training. After qualifying he applied to join the Indian Medical Service. The entrance exams were incredibly stiff: six hours a day for five days, he recalls, and this was followed by several months' training at the Royal Army Medical College at Millbank and then Aldershot, learning the skills of soldiering, etiquette for officers, and how to ride, for the Indian Medical Service was a cavalry service.

By 1912 he was back in India, in Benares, as medical officer to the 62 Punjabi Regiment and here he met his first major medical challenge in the form of a cholera epidemic among a company of British troops. He also took up the challenge of learning Urdu, for officers were not paid their wages in full until they could read, write, and speak the language fluently.
When war broke out in 1914 he was sent to Mesopotamia with the Mesopotamian Expeditionary Force. Memories of his first hand to hand fighting on horseback against a company of Turks have not faded nor has a distinctly non-military skirmish with the banks of the Shat-el-Arab river at the head of the Arabian Gulf. "We were heading up river on the Sofola, complete with the regiment's horses, camels, and field equipment, when we struck the boat in front and suddenly listed. The captain sent the Chinese carpenter down into the hold to assess the damage. He returned in a state of great agitation. 'Four foot of water in the hold, sir.'" Mindful of the 500 horses tethered down below the captain rammed the boat into the shore to ensure that it was well and truly grounded. Seconds later an abject carpenter returned. He had made a mistake; he had sounded the water tank and the hold was as dry as a bone. Luckily the captain was able to float the boat off later in the day; otherwise it would have effectively obstructed the progress to Basra of the bulk of the expeditionary force.

From amputations in the field, dealing with typhus, typhoid fever, dysentery, relapsing fever, oriental sore, and heat stroke in the troops, to overseeing all antimalarial measures in the Middle East-and learning ArabicColonel Shortt's experience was broad. His main interest, however, was always laboratory work and in 1916 he joined the central reference laboratory at Basra, later moving to Baghdad. It was here that he established what proved to be a lifelong friendship with Sir Ricard Christophers, who was the director of the unit. The colonel is still moved when he speaks of this "remarkable, yet unfailingly modest" man, who was one of the most distinguished members of the Indian Medical Service. At this time, too, he met the equally remarkable Hobby (Eleanor Hobson), who was working as a sister in Iraq in the Queen Alexandra Military Nursing Service.

\section{$\mathbf{9 0 \%}$ Death rate to $90 \%$ cure rate}

After the war Colonel Shortt was posted to a hill station in the lower Himalayas, and it was here at Kasauli, then India's foremost research institute, that he consolidated his interest in protozoal parasites, especially Leishmania donovani. At that time kala azar had a high morbidity and once a village was affected it soon became moribund as so few fit people were left to cultivate the land. Later, at the Kala Azar Commission in Assam, he worked exhaustively on the disease and in 1924, in association with Dr U N Brahmachari, established urea stibamine as the first satisfactory treatment. It was a dramatic success, said the colonel, "Overnight, a death rate of $90 \%$ was transformed into a cure rate of $90 \%$." His main research interest at this time, however, centred on the transmission of the disease, which he was convinced was spread by sandflies. After repeatedly 
unsuccessful experiments to prove this hypothesis in mice, Chinese hamsters, and monkeys he decided that the next step was to conduct experiments in man-the disease's natural host. He submitted a research proposal to the authorities in Simla and promptly received "The worst stinker of a letter that I have ever had." Don't ever mention the word human volunteers again, he was told. He didn't, and a second application, identical apart from the offensive words, and entitled "proposals for research with insects" gained instant approval.

I was fascinated to hear how the experiments were done and needless to say the colonel remembered every detail. In essence, sandflies were bred in special cages and then taken to a village where most of the inhabitants were infected with kala azar. Volunteers from among those infected stuck their arms in the cage to allow the sandflies to feed on them. Replete, the sandflies were taken back to the lab and a week later were let out into a special insect proof room in which six healthy volunteers had been introduced. They had been recruited from a village up country that was free of the disease. After their exposure was deemed adequate the men were transported back to their village and kept under close observation. All subsequently developed, and were of course treated for, kala azar. This proof that Phlebotomus argentipes was the vector rapidly gained acceptance world wide.

Work on kala azar then gave way to work on rabies, which he studied when a director of the Pasteur Institute in Kasauli. Then smallpox vaccine, antivenin, cholera vaccine, dengue, and babesiosis, which were his main interests in Madras, where he was director of the King Institute of Preventive Medicine from 1933 to 1934. While working here he also described (for the first time) the condition of fluorosis, which he came across in an isolated district in southern India, where "not only the people but their cattle, too, became progressively stiff and rheumaticky over 20 to 30 years, until they could scarcely move." They also developed peculiar bony growths. Colonel Shortt traced the problem to the wells, the sole source of water for the region, which were heavily contaminated with fluorine.

\section{Fishing and firewalking}

In common with enthusiastic research workers the world over, Colonel Shortt was no observer of conventional working hours, but Hobby ensured that he participated in the social side of life. This was, after all, the India of the raj and every hill station had its tennis parties, drinks parties, picnics, etc, and by this time the Shortts had two children. Meanwhile the colonel needed no encouragement to go hunting, whether for leopard, crocodile, buffalo, or, by contrast, pigeon and snipe, and of course to fish and pursue his interest in natural history and archaeology. The colonel still goes trout fishing every week but has keen memories of catching 80 to $90 \mathrm{lb}$ mahseer in India and of the time that he hooked a cannibal trout, which, after an exhaustive play, emerged from the water with a second fish clamped around its jaws.

With work taking the Shortts the length of India there was plenty of scope for observing the country's wealth of different cultural practices. These included firewalking, head hunting-I saw an alarming photograph to prove it-and ritual human sacrifice-on this occasion the husband of one of their servants was abducted and slaughtered to appease a cobra.

From Madras, where his last post was acting surgeon general of public health, Colonel Shortt returned to England to the London School of Hygiene and Tropical Medicine but was soon back in India with the outbreak of the second world war, this time as inspector general of civil hospitals and prisons in Assam. Much of his time was spent organising refugee camps set up to cope with the mass exodus of refugees fleeing from the Japanese in Burma. In a

British Medical Journal, London WC1H 9JR

TESSA RICHARDS, MRCP, MRCGP, assistant editor biographical note it is recorded that out of his force of 1013 men only 23 survived.

In 1945, back at the London School of Hygiene and Tropical Medicine as professor of medical protozoology, he worked on malaria and with his reader, P C C Garnham, discovered the exoerythrocytic stage of Plasmodium vivax with its passage through the liver. One of the several honours that he subsequently received and the one that he holds most dear is his fellowship of the Royal Society, to which he was elected in 1950.

\section{Still "doing a bit of research"}

Officially retired in 1951 he promptly went out to Dacca and set up an Institute of Public Health. Then it was back to the London School and more work, this time on babesiosis. When a Festschrift in honour of his 80th birthday was published the $B M \mathcal{F}$ later recorded that the official award ceremony had had to be delayed for the colonel was in Nairobi "doing a bit of research."

Africa was a "disappointment" after India, and it is not hard to see why. India provided Shortt the researcher with incomparable challenges and Shortt the sportsman with opportunities that were no less challenging. On one notable occasion he was out shooting buffalo and got within yards of a huge herd when he suddenly tripped and fell, twisting his ankle. On regaining his feet he found that his bearers had fled and the massive beasts were thundering towards him. Convinced that he would be trampled to death he stood his ground. Miraculously, the leader swerved at the last moment and the whole herd veered off behind it.

Some time later he and Hobby, who was in England at the time, compared notes. At the exact time of this event she had woken with a terrible nightmare, convinced that her husband was in danger, and had remained miserably apprehensive until she heard from him.

Whatever your views about telepathy it is clear that the partnership between Colonel and Mrs Shortt has been very special. At 101 years old herself Hobby still has immense vitality and a great sense of humour. She also remembers their life in India with astonishing clarity and over tea regaled me with stories including one about her wedding in Calcutta in 1921 "among the harvest festival cabbages and peas" when the colonel in full dress uniform knelt beside her at the altar, and unceremoniously dug his spurs into his knee.

There can be few couples who are still living together independently at the age of 100 , and fewer still who have led such full and rewarding lives. Who could wonder that, given the opportunity, the colonel would "do it all over again."

Is there any evidence to support the use of amphetamines in combating the fatigue associated with multiple sclerosis?

Fatiguability may be a prominent, early, and persistent symptom of multiple sclerosis. Tiredness and muscular weakness are common and these symptoms may lead to a false diagnosis of narcolepsy. ${ }^{1}$ Conversely, transient visual disturbances and gait problems are occasionally reported by patients with narcolepsy as a consequence of their excessive daytime somnolence. Taking the corollary of poliomyelitis, where lower not upper motor neurons are affected, if fewer nerves are working to a limb that limb will fatigue more easily than normal. Fatiguability with multiple sclerosis may also be associated with heavy carbohydrate meals and a hot environment. The standard advice for such fatigue is "to exercise moderation in all activities by maintenance of a reasonable standard of physical fitness, and, if necessary, by weight reduction."' There is no justification for using amphetamines. Even when driving a vehicle, the individual with multiple sclerosis is not especially prone to silly errors or to falling asleep at the wheel as may occur with narcolepsy or other sleep disorders.-E M R CRITCHLEY, consultant neurologist, Preston.

1 Poirier G, Montplaisir J, Dumont M, et al. Clinical and sleep laboratory study of narcoleptic symptoms in multiple sclerosis. Neurology 1987;37:693-5.

2 McAlpine D, Lumsden CE, Acheson ED. Multiple sclerosis: a reappraisal. 2nd ed. Edinburgh: Churchill Livingstone, 1972 